\title{
TOWARDS 2000: STRATEGIES TO ACHIEVE MORE EFFICIENT FERTILISER USE IN INLAND SOUTH ISLAND HILL AND HIGH COUNTRY
}

M.J.S. FLOATE', C.C. BOSWELL', B.E. ALLAN', and D. SCOTT ${ }^{2}$ $1 /$ nvermay Agricultural Centre, MA..F Mosgiel ${ }^{2}$ Grasslands Division, DSIR, Lincoln

Abstract

The future approach to efficient fertiliser use on hill and high country pastures must increasingly recognise that most farms are a complex mosaic of widely different environments - with an associated range in production potential, carrying capacity and fertiliser requirement. Although the importance of broad regional soil patterns has been recognised in the past, little allowance has been made for significant local landscape and soil variations.

The plant nutrient needs of component parts of the landscape mosaic can be assessed by soil testing and met by fertiliser materials whosequantityand composition match those nutrien requirements in most situations.

Strategies should be developed to ensure that fertiliser regimes, pasture plants and management practices are selected and orchestrated to make the most effective use of each mosaic component on each individual farm. In effect this involves selective fertiliser use, geared to the limitations, characteristics and growth patterns of individual landscape units, which are managed to meet the seasonal feed requirements of stock in the most cost effective way.

A case study of Tara Hills is presented, showing how selective use of fertiliser on individually fenced landscape units can be matched to the use of these units (paddocks or blocks) in a management system designed to fit the seasonal stock feed requirements for a high country pastoral run.

Finally the importance of plant requirements, soil properties, grazing management, fertiliser form and composition, and spreading methods are reviewed with respect to fertiliser efficiency in the hill and high country.

\section{INTRODUCTION}

Fertilisers are applied to increase herbage production by correcting natural deficiencies in nutrient supply or to replenish nutrients used up in pastoral farming. In the South Island hill and high country this has been traditionally achieved by the widespread use of superphosphate, sulphur superphosphate and molybdenum, and until recently the choise of other, more appropriate fertilisers has been very restricted. Although the importance of broad regional soil differences has been recognised in the past, (Ludecke \& Leamy 1972; Sinclair \& McIntosh 1983) little allowance has been made for significant local landscape and soil variations. Economics of fertiliser use are necessitating change. Fertiliser use has until recently been aimed at maximising production, but in the high country and in the present economic climate this is not necessarily the best objective: the emphasis is shifting to maximum economic efficiency. This will only be attained when nutrient supply is the greatest limitation to pasture production so the relative importance of climatic and management factors must first be established. We shall show how these considerations will result in more effective use of the wider range of fertiliser materials which are becoming available. This paper is divided into two parts. First we shall consider the role of fertiliser in the context of whole farm planning, and best resource utilisation. Second, we shall consider factors affecting pasture responses to fertiliser.

\section{FERTILISER EFFICIENCY AND FARM PLANNING}

Fertiliser can be an important item in the hill and high country farm budget. Kane (1983) estimated fertiliser accounted for $43 \%$ of his annual running costs (exclusive 
of interest and principal payments) at that time. Fertiliser use should therefore be considered in the whole farm context. Overall farm strategy should aim to fit the choice of fertiliser to suit animal enterprise, pasture type and grazing management within the limitations of climate and landscape, and the availability of capital and labour.

The physical limitations, largely unchangeable, and the opportunities for choice for each of 5 factors affecting production are illustrated in Figure 1. Permanent constraints due to landscape (because of altitude and aspect) leave no room for choice at the top of the scale, while at the bottom there is unrestricted opportunity for management choice. Other factors have varying degrees of restriction and soil fertility, for example, may be permanently limited by soil depth or stoniness, but there is opportunity for increasing the nutrient supply.

\begin{tabular}{|c|c|c|c|c|}
\hline \multirow{6}{*}{\multicolumn{2}{|c|}{ 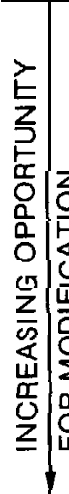 }} & $\begin{array}{c}\text { Factors affecting } \\
\text { production }\end{array}$ & Constraints & $\begin{array}{l}\text { Opportunities for } \\
\text { modification }\end{array}$ \\
\hline & & LANDSCAPE & $\begin{array}{l}\text { ALTITUDE } \\
\text { ASPECT }\end{array}$ & NIL \\
\hline & & CLIMATE & $\begin{array}{l}\text { RAINFALL } \\
\text { TEMPERATURE }\end{array}$ & IRRIGATION \\
\hline & & SOIL & $\begin{array}{c}\text { DEPTH, TEXTURE } \\
\text { LOW NUTRIENT STATUS }\end{array}$ & FERTILISER, LIME \\
\hline & & VEGETATION & $\begin{array}{l}\text { RESIDENT } \\
\text { SPECIES }\end{array}$ & $\begin{array}{l}\text { PASTURE SPECIES } \\
\text { AND VARIETIES }\end{array}$ \\
\hline & & MANAGEMENT & $\begin{array}{c}\text { CAPITAL } \\
\text { TECHNOLOGY }\end{array}$ & $\begin{array}{c}\text { LIVESTOCK, FENCING, } \\
\text { GRAZING }\end{array}$ \\
\hline
\end{tabular}

Figure 1: Diagramatic representation of constraints affecting opportunities for choice in management strategies for hill and high country farming.

The aim should be to match, as closely as possible, the supply of feed from pasture, to the seasonal demands of livestock by manipulating pasture type, grazing management and fertiliser use within the constraints discussed above. To apply these principles requires a thorough understanding of the climatic, land and other resources of the whole farm.

A generalised landscape, incorporating temperature and moisture gradients is illustrated in Figure 2a. This shows the distribution of zonal soils from the browngrey earths in the warm dry basins of Central Otago to the podzolised yellow-brown earths of the high country near the main divide.

Within this landscape we can take an enlarged view (Fig $2 b$ ) of part of this range showing the schist hills $(\mathrm{h})$, lower slopes $(\mathrm{s})$, alluvial fans $(\mathrm{f})$, outwash terraces $(\mathrm{t})$ and recent alluvium (a). These landscape units can be subdivided further into paddocks and blocks (Fig 2c) so that appropriate use can be made of each unit. Moisture supply is the overriding limitation on the lower sunny slopes in summer when growth potential is less restricted by temperature on the schist hills.

The key is to identify where the shortfall between feed supply and demand is most critical for the property and to determine whether or not it can be overcome economically by the application of fertiliser. Fertiliser may be applied to a specific block or several blocks to meet the shortfall. When more than one shortfall is identified, an order of priorities can be established for fertiliser use (Kane 1983). Once the critical need is established, the next step is to determine the nutrient requirements and fertilisers to meet that need. 

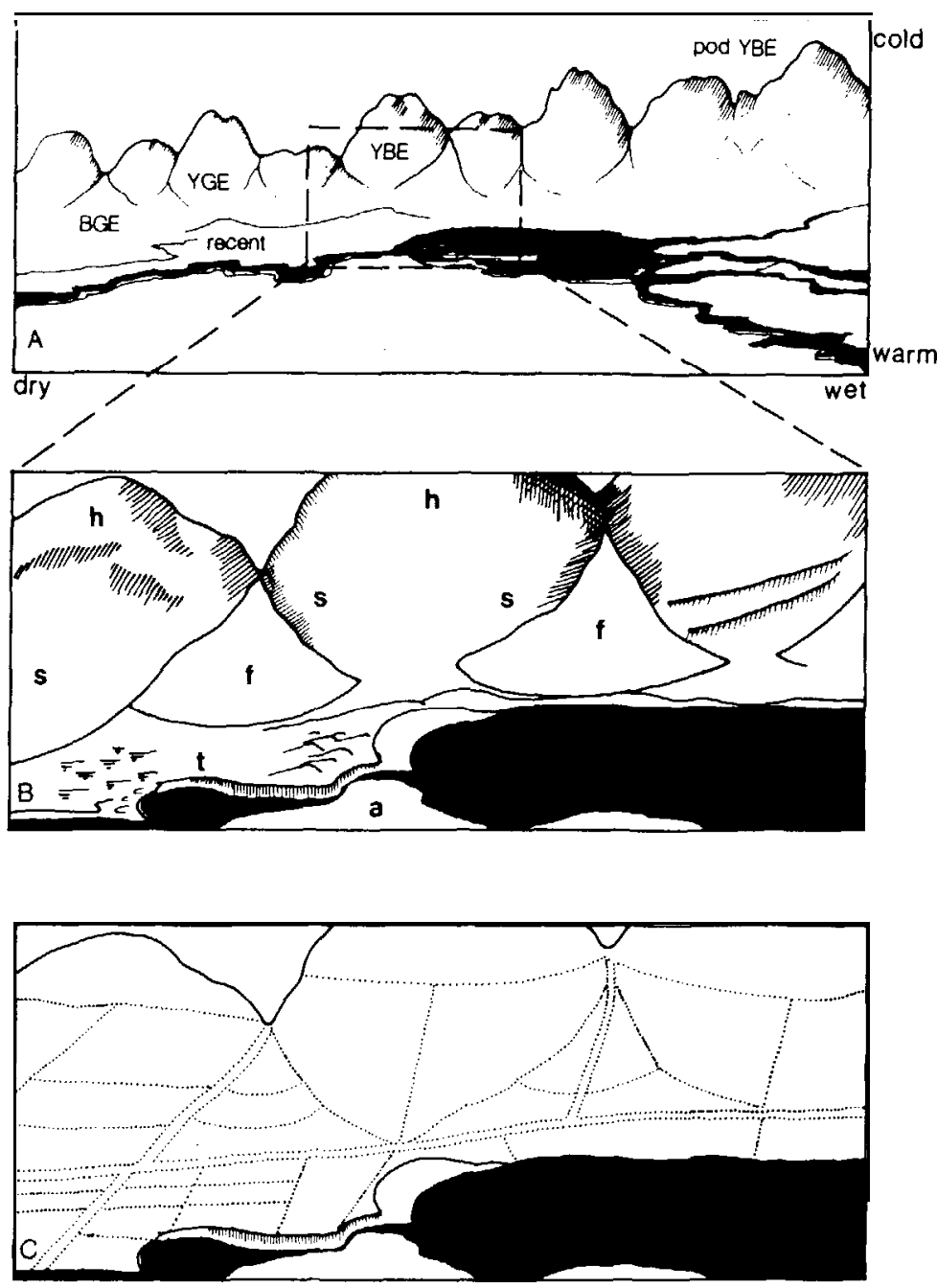

Figure 2: Idealised diagram of hill and high country showing (a) the distribution of zonal soil types, (b) landscape units, and (c) how these could be subdivided into paddocks and blocks.

To illustrate the fertiliser inputs required to maintain pasture productivity from the mosaic of landscape units which may be found on a property, the recommended maintenance fertiliser requirements for seven different units on the Tara Hills High Country Research Station are shown in Table 1. The recommendations were derived from the MAF computerised fertiliser advisory service (CFAS) based on models described by Cornforth and Sinclair (1984). The table shows the characteristics and probable utilisation of each of these units, and for two of them alternative pasture types are suggested. The recommended rate of fertiliser is closely related to stocking rate and expected production, while composition (P:S ratio) is more 
Table 1: Matching fertiliser use to landscape units: Tara Hills case study.

\begin{tabular}{|c|c|c|c|c|c|c|c|c|c|c|}
\hline \multirow{3}{*}{$\begin{array}{l}\text { Landscape } \\
\text { Unit } \\
\text { Upper }\end{array}$} & \multirow{3}{*}{$\begin{array}{c}\text { Soil } \\
\text { type }\end{array}$} & \multirow{3}{*}{$\begin{array}{c}\text { Physical } \\
\text { Limitations } \\
\text { low } \\
\text { temperature }\end{array}$} & \multirow{3}{*}{$\begin{array}{c}\text { season } \\
\text { of pasture } \\
\text { growth }\end{array}$} & \multirow{3}{*}{$\begin{array}{c}\text { Stocking } \\
\text { rate } \\
\text { (SU/ha) } \\
\text { utilisation }\end{array}$} & \multirow{2}{*}{\multicolumn{2}{|c|}{$\begin{array}{l}\text { CFA } \\
\text { Nutr- } \\
\text { ients } \\
\text { needed } \\
\text { (kg/hă }\end{array}$}} & \multicolumn{2}{|c|}{$S$ recommendations for } & \multirow{2}{*}{\multicolumn{2}{|c|}{$\begin{array}{c}\text { maintenance } \\
\text { Nutr- } \\
\text { ients } \\
\text { applied } \\
\text { (kg/hâ }\end{array}$}} \\
\hline & & & & & & & $\begin{array}{l}\text { Fertiliser } \\
\text { Material }\end{array}$ & $\begin{array}{l}\text { Rate } \\
\text { (kg/ha) }\end{array}$ & & \\
\hline & & & & & 2 & 6 & $\begin{array}{l}\text { Sulphur } \\
\text { super }\end{array}$ & 30 & 2 & 6 \\
\hline Mid sunny & $\begin{array}{c}\text { y Kaikoura (a } \\
\text { (YBE) }\end{array}$ & $\begin{array}{l}\text { a) summer } \\
\text { moisture } \\
\text { (b) short } \\
\text { growing } \\
\text { season }\end{array}$ & $\begin{array}{l}\text { spring } \\
\text { autumn } \\
\text { winter }\end{array}$ & 2.0 & 2 & 5 & $\begin{array}{l}\text { Sulphur } \\
\text { super }\end{array}$ & 30 & 2 & 6 \\
\hline $\begin{array}{l}\text { Low-mid } \\
\text { shady }\end{array}$ & $\begin{array}{l}\text { Omarama } \\
\text { (YGE) }\end{array}$ & $\begin{array}{l}\text { (a) short } \\
\text { growing } \\
\text { season } \\
\text { (b) summer } \\
\text { moisture }\end{array}$ & $\begin{array}{l}\text { late spring } \\
\text { summer } \\
\text { early } \\
\text { autumn }\end{array}$ & 3.0 & 3 & 6 & $\begin{array}{l}\text { Sulphur } \\
\text { super }\end{array}$ & 40 & 3 & 6 \\
\hline $\begin{array}{r}\text { Low sunny } \\
\text { (pasture) }\end{array}$ & $\begin{array}{c}\text { Omarama) } \\
(\mathrm{YGE})\end{array}$ & moisture , & $\begin{array}{l}\text { spring } \\
\text { | autumn } \\
\text { winter }\end{array}$ & 1.5 & 1 & 6 & $\begin{array}{l}\text { Sulphur } \\
\text { super extra }\end{array}$ & 20 & 1 & 5 \\
\hline $\begin{array}{l}\text { Low sunny } \\
\text { (lucerne) }\end{array}$ & $\begin{array}{c}\text { Omarama) } \\
(Y G E)\end{array}$ & j & & 4.0 & 3 & 1 & super & 40 & 3 & 4 \\
\hline Fans & $\begin{array}{l}\text { Grampians } \\
\text { (BGE) }\end{array}$ & moisture & $\begin{array}{l}\text { spring } \\
\text { autumn }\end{array}$ & 4.0 & 3 & 10 & $\begin{array}{l}\text { Sulphur } \\
\text { super }\end{array}$ & 50 & 3 & 10 \\
\hline $\begin{array}{l}\text { Outwash } \\
\text { (dryland) }\end{array}$ & $\begin{array}{c}\text { Mackenzie } \\
\text { (YBE) }\end{array}$ & moisture & $\begin{array}{l}\text { spring } \\
\text { autumn }\end{array}$ & 1.5 & 1 & 6 & $\begin{array}{l}\text { Sulphur } \\
\text { super extra }\end{array}$ & 20 & 1 & 5 \\
\hline $\begin{array}{l}\text { Outwash } \\
\text { (irrigated) }\end{array}$ & $\begin{array}{c}\text { Mackenzie } \\
\text { (YBE) }\end{array}$ & nil & $\begin{array}{l}\text { spring } \\
\text { summer } \\
\text { autumn }\end{array}$ & 10 & 10 & 4 & super & 130 & 10 & 14 \\
\hline $\begin{array}{c}\text { Recent } \\
\text { (irrigated) }\end{array}$ & $\begin{array}{l}\text { Tasman } \\
\text { (Recent) }\end{array}$ & nil & $\begin{array}{l}\text { spring } \\
\text { summer } \\
\text { autumn }\end{array}$ & $\begin{array}{c}\text { (8 tha) } \\
\text { hay }\end{array}$ & 16 & 3 & super & 200 & 16 & 22 \\
\hline
\end{tabular}

dependent upon landform and pasture type. There is a good match between calculated nutrient requirements and available fertiliser except in two cases, on irrigated outwash and recent soils, where the P:S ratio of superphosphate is too high to match nutrient needs. This will be readily overcome by the advent of high analysis fertilisers which have the added advantages of reduced transport and application costs.

In the event of restricted finances being available for fertilisers the following practicalities arise: (a) Highest priority for fertiliser should be to meet critical feed shortages. (b) On newly developed blocks it is generally better to apply the full rate to a smaller part of the block and (c) Reduced fertiliser input (and greater fertiliser efficiency) is possible without reducing stock numbers if pasture utilisation can be increased. $65 \%$ utilisation was assumed for all dryland pastures at Tara Hills; lower levels of utilisation common on many properties allow more scope for improved efficiency.

\section{FACTORS AFFECTING PASTURE RESPONSES TO FERTILISER}

\section{Plant nutrient requirements}

The choice of different pasture plants for a given block or paddock may alter fertiliser requirements. For example at common sites in the Otago Uplands, where the alternative legumes were lotus or clovers, lotus gave near maximum yields with 
the lowest rate of $P(20 \mathrm{~kg} / \mathrm{ha}$ at establishment, followed by $10 \mathrm{~kg} P / \mathrm{ha}$ annually) whereas clovers responded to at least double these rates of $P$ (Mclntosh et $d$. P84).

\section{Soil properties}

Ludecke and Leamy (1972) and Sinclair and McIntosh (1983) have shown that there is a geographic pattern to the general distribution of nutrient deficiencies across the range of zonal soils from brown-grey through yellow-grey to yellow-brown earths in the South Island hill and high country. This broadly shows that S-deficiency is widespread and acute throughout the range of hill and high country soils in the South Island while P-deficiency gets progressively more acute as soils are more strongly leached. Thus yellow brown earth soils are generally deficient in both Sand $\mathrm{P}$, but Floate and Risk (unpubl. data) have demonstrated important local variations on the Remarkables. Both soil tests and field trials on contrasting sites (Site 1, Olsen $\mathrm{P}=4, \mathrm{SO}_{4}-\mathrm{S}=23$; Site 2, Olsen $\mathrm{P}=41, \mathrm{SO}_{4}-\mathrm{S}=6$ ) demonstrated the dominant need for $P$ at site 1 and for $S$ at site 2 . There are other soil properties which increase the amount of fertiliser required to maintain pasture and so reduce production per unit of fertiliser input. Some soils (e.g. yellow-brown loams) are highly retentive of $P$, while others are characterised by high leaching losses (e.g. S on shallow, stony soils).

Table 2: Comparison of fertiliser application strategies.

\begin{tabular}{|c|c|c|c|c|c|c|}
\hline $\begin{array}{l}\text { Application } \\
\text { Rate } \\
\text { (kg/ha) }\end{array}$ & $\begin{array}{r}\begin{array}{c}\text { Area } \\
\text { treated }\end{array} \\
\text { (ha) }\end{array}$ & $\begin{array}{l}\text { Weight of } \\
\text { Fertiliser } \\
\text { applied } \\
\text { (tonne) }\end{array}$ & $\begin{array}{c}\text { Fertiliser } \\
\text { cost } \\
(\$ 160 \text { per } \\
\text { Ionne })\end{array}$ & $\begin{array}{c}\text { Spreading } \\
\text { cost } \\
\text { (\$ per } \\
\text { tonne) }\end{array}$ & $\begin{array}{c}\text { Application } \\
\text { Cost } \\
\text { (\$) }\end{array}$ & $\begin{array}{c}\text { Total } \\
\text { cost } \\
(\$)\end{array}$ \\
\hline \multicolumn{7}{|c|}{ 1. Whole block fertilised - fixed wing plane } \\
\hline 100 & 100 & 10 & 1600 & 40 & 400 & 2000 \\
\hline 2. Exclusion of & $20 \%$ of block & lies (waste & - helico & & & \\
\hline
\end{tabular}

\section{Grazing management}

By definition, improved pasture utilisation will improve fertiliser efficiency by avoiding wastage of pasture grown, accelerating the rate of nutrient recycling, and ensuring more nearly uniform nutrient return. Subdivision is necessary to achieve better utilisation, and for greatest effect fencing should coincide with the boundaries of landscape units as shown in Fig $2 \mathrm{c}$.

\section{Fertiliser composition}

In the past a restricted range of fertiliser materials was available with a limited range in proportions of the major nutrients $P$ and $S$. There will be an increasingly wider choice of materials both with respect to composition and availability of plant nutrients.

Among the $\mathrm{P}$ and $\mathrm{S}$ fertilisers available in New Zealand superphosphate contains $9 \%$ and $11 \% \mathrm{~S}$ both of which are in soluble form and are readily available for plant uptake. The moderately high analysis $S$ fertilisers sulphur superphosphate $(19 \%$ S) and S super extra $(27 \%$ S) contain soluble $\mathrm{P}$ and $\mathrm{S}$ and also insoluble elemental sulphur $(\mathbf{S} \% \mathrm{~S}$ /sodium bentonite prills now offer a very high (up to $90 \%$ ) $\mathrm{S}$ content material. Similarly di-ammonium phosphate (DAP) which contains $20 \% \mathrm{P}$, $2 \% \mathrm{~S}$ and triple superphosphate $(20 \% \mathrm{P}, 1 \% \mathrm{~S})$ offer materials with much higher $\mathrm{P}$ contents than superphosphate. In these materials the $P$ is in a soluble phosphate form, which is immediately available and suitable for pasture establishment.

Reactive phosphate rock (RPR, $13.17 \% \mathrm{P}$ ) and $\mathrm{S}^{\circ}$ are less readily available to pasture plants. Availability depends upon the speed of chemical reaction of RPR in moist acidic $(<\mathrm{pH} 5.5)$ soil, and the rate of biological oxidation of $\mathrm{S}^{\circ}$, both of which are inversely related to particle size and increase with soil temperature. Availability can thus be at least partially controlled by fertiliser manufacture and materials could 
be offered to suit different conditions. Most high analysis $P$ fertifisers (e.g. RPR, triple super and PAPR made with phosphoric acid) contain little or no S. PAPR can be made with sulphuric acid to give fertilisers with $11.15 \% \mathrm{P}$ and $3.8 \% \mathrm{~S}$. There is considerable potential for mixing high analysis $\mathrm{P}$ and $\mathrm{S}$ materials to match the specific $P$ and $S$ requirements of any situation, and mixtures of granulated triple superphosphate or PAPR with prilled $\mathbf{S} \%$ bentonite would be ideal.

\section{Method of application}

Aerial application can suffer from inefficiencies caused by uneven application resulting from missing strips and double flying strips, or inaccuracies at low fertiliser application rates (Gillingham 1981). Uneven application may result in up to $50 \%$ of the ground to be treated receiving little or no fertiliser (Macfarlane et al. in this volume) and up to $24 \%$ loss in pasture response (Hilder \& Vickery 1980).

There are opportunities for improved evenness of spreading, and avoidance of waste application in non-productive areas. Evenness of spreading is related to the range of particle sizes present in the material, and to wind conditions at the time of spreading (Macfarlane et al. in this volume). The use of such aids as powered spreading and radar guidance systems (Hedderwick \& Will 1982) also gives improved distribution and accuracy of spreading. 'Helicopters are suitable for both modifications and although more example, where application by plane cannot in practice avoid wastage in non-responsive gullies in dissected blocks, and at low rates of application. In the example shown in Table 2, where a block contained $20 \%$ of non-productive ground, the savings in amount of fertiliser justified the extra cost of helicopter application.

\section{Time of application}

When nutrient supply exactly matches plant growth needs, losses and wastage are minimised. In extensively grazed hill and high country pasture emphasis should be placed on slow release fertilisers so that nutrient requirements are met from a biennial or even triennial application of fertiliser. Since the release of available $P$ and $S$ from such fertilisers is dependent on temperature and moisture, nutrients are available at the time of greatest plant growth potential, which matches plant needs.

\section{References}

Cornforth I.S., Sinclair A.G. 1984. Fertiliser recommendations for pasture and crops in New Zealand. Ministry of Agriculture and Fisheries, Wellington, NZ.

Gillingham A.G. 1981. Agronomic aspects in Proceedings of a Workshop on Aerial Fertiliser Application, Hamilton. pp 2.5. NZ Agricultural Engineering Institute and Ministry of Agriculture and Fisheries.

Hedderwick, G.W., Will. G.M. 1982. Aerial topdressing of forests. Whats new in Forest Research No. 114. Forest Research Institute, Rotorua, NZ.

Hilder E.J., Vickery P.J. 1981. Effect of uneven distribution of superphosphate on pasture production. Proceedings of the Australian Society of Animal Production 13: 470.471.

Kane A. 1983. How I handle my fertiliser programme. Proceedings of the 1983 Hill and High Country Seminar pp 45.48. Centre for Resource management. Lincoln, NZ.

Ludecke T.E., Leamy M.L. 1972. Fertiliser use and grassland improvement on Central Otago hill and mountain soils. Tussock Grassland and Mountain Lands Institute Review 25: 14-21.

Mclntosh P.D., Enright P.D., Sinclair A.G. 1984. Fertilisers for lotus and clover establishment on a sequence Of acid soils on the East Otago uplands. NZ Journal Experimental Agriculture 12: 119-129.

Sinclair A.G., Mclntosh P.D. 1983. Soils and fertilisers for pasture production in the South Island hill and high country. Proceedings of the $1983 \mathrm{HIII}$ and High Country Seminar pp 27-34. Centre for Resource Management, Lincoln, NZ 